\title{
Evaluation of the Functional and Radiological Outcomes of Serial Casting as an Initial Treatment of Congenital Scoliosis
}

\author{
Konjenital Skolyozun Illk Tedavisi Olarak Seri Alçılama Tekniğinin Fonksiyonel ve \\ Radyolojik Sonuçlarının Değerlendirilmesi
}

(Dinan Erdoğan, (1) Ethem Ayhan Ünkar, (D) Deniz Kargın, (D) Altar Çolak, (D) Akif Albayrak

Metin Sabancı Baltalimanı Bone Diseases Training and Research Hospital, Clinic of Orthopaedics and Traumatology, İstanbul, Turkey

\begin{abstract}
Introduction: It has been reported that serial casting is an effective treatment method in early-onset idiopathic scoliosis, but its role in congenital scoliosis has not been clarified. This study aimed to evaluate the efficacy of serial castings in young children with congenital scoliosis and to discuss whether serial casting can be used effectively to delay surgical procedures.

Methods: Patients between the ages 2 and 5 years with congenital scoliosis who had a Cobb angle above 25 degrees and had not undergone any surgical treatment between 2016 and 2019 were included in this study. Cast changes were performed at 3-month intervals. Radiographic evaluations were performed on posteroanterior and lateral orthoroentgenograms in the cast on the first day after the cast application and at the last follow-up visit.
\end{abstract}

Results: A total of 10 patients (6 female, 4 male) with long congenital curves with mixed type formation or segmentation anomalies were included in the study. The mean number of cast applications was 4 for each patient (range: 3 to 6). The initial casting age was 3.2 (range: $2-4$ years). The mean followup period was 15.1 months (range: $12-23$ months). The mean precasting Cobb angle was 61.9 \pm 13.7 degrees (range: 38-76 degrees), which was reduced to $43.4 \pm 12.8$ degrees (range: 24-58 degrees) after the initial casting, and it was $48.4 \pm 12.6$ degrees (range: 28-63 degrees) at the latest follow-up. The mean precasting T1-T12 length was $223 \pm 27.3 \mathrm{~mm}$ (range: 176 $271 \mathrm{~mm}$ ). After the initial cast application, T1-T12 length was $241.8 \pm 27.5 \mathrm{~mm}$ (range: $189-285 \mathrm{~mm}$ ). At the last follow-up, the average T1-T12 length was 254 $\pm 27.6 \mathrm{~mm}$ (198, $290 \mathrm{~mm})$.

Conclusion: In early-onset scoliosis, even when growthfriendly methods were occupied, spontaneous fusion may develop. Serial casting under anesthesia allows for lengthening by controlling the progression of the deformity. This method can provide more time for the patient to delay surgical interventions.

Keywords: Congenital scoliosis, serial casting, non-surgical scoliosis treatment

\section{öZ}

Amaç: Erken başlangıçlı idiyopatik skolyozda seri alçılama uygulamalarının etkili bir tedavi yöntemi olduğu literatürde bildirilmiștir; ancak bu yöntemin konjenital skolyozdaki rolü yeteri kadar araștırılmamıştır. Bu çalışmanın amacı, konjenital skolyozlu çocuklarda seri alçılama tekniğinin etkinliğini değerlendirmek ve seri alçılamanın cerrahi prosedürleri geciktirmek için etkili bir şekilde kullanılıp kullanılamayacağını tartışmaktır.

Yöntemler: 2016-2019 yılları arasında 2-5 yaş aralığında etiyolojisi konjenital skolyoz olan ve Cobb açısı 25 derece üzerinde olup herhangi bir cerrahi tedavi geçirmemiş hastalar çalışmaya dahil edildi. Rutin alçı değişiklikleri 3 aylık aralıklarla yapıldı. Alçı uygulamasından sonraki gün ve son takipte alçıda alınan standart ayakta posteroanterior ve lateral radyografilerde spinal ölçümleri yapıldı.

Bulgular: Çalıșmaya 6 kız, 4 erkek toplam 10 hasta dahil edildi. Ortalama 4 kez alçılama yapıldı (minimum: 3-maximum: 6). ilk alçılama yaşı 3,2'ydi (minimum: 2- maximum 4). Takip süremiz ortalama 15,1 ay (minimum: 12, maximum: 23) idi.

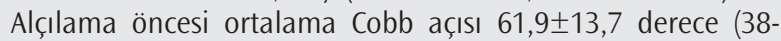
76), ilk alçılama sonrası $43,4 \pm 12,8$ derece (24-58), son takipte 48,4 $\pm 12,6$ derece (28-63) olarak değerlendirildi. Alçılama öncesi T1-T12 uzunluğu 223 27,3 mm (176-271 mm) idi. Illk alçılama sonrası T1-T12 uzunluğu 241,8 27,5 mm (189-285) idi. Son takipte, ortalama T1-T12 uzunluğu 254 $\pm 27,6$ mm (198, $290 \mathrm{~mm}$ ) olarak bulundu.

Sonuç: Erken başlangıçlı skolyozda büyüme dostu cerrahi yöntemlerde dahi cerrahi prosedürler nedeniyle anatomik yapılar zarar görmekte ve sponton füzyon gelişebilmektedir. Anestezi altında seri alçılama, eğriliğin ilerlemesini kontrol altında tutarak boy uzamasına imkan vermekte ve cerrahi müdahaleleri geciktirmekte güvenli ve etkili bir zaman kazanımı sağlamaktadır. Hastaya herhangi bir cerrahi girişim yapılmadığı için cerrahi girișimlerin büyüme üzerine olumsuz etkileri olmadığından boy uzamasını engellemeden hastalara zaman kazanımı sağlanabilmektedir.

Anahtar Kelimeler: Konjenital skolyoz, seri alçılama, cerrahi dışı skolyoz tedavisi
Address for Correspondence/Yazışma Adresi: Sinan Erdoğan MD, Metin Sabancı Baltalimanı Bone Diseases Training and Research Hospital, Clinic of Orthopaedics and Traumatology, İstanbul, Turkey

Phone: +90 5333064182 E-mail: sinanerdogan@hotmail.com ORCID ID: orcid.org/0000-0002-8517-3925

Cite this article as/Atıf: Erdoğan S, Ünkar EA, Kargın D, Çolak A, Albayrak A. Evaluation of the Functional and Radiological Outcomes of Serial Casting as an Initial Treatment of Congenital Scoliosis. Istanbul Med J 2020; 21(1): 18-22.

(c) Copyright 2020 by the Istanbul Training and Research Hospital/istanbul Medical Journal published by Galenos Publishing House.

(C) Telif Hakkı 2020 istanbul Ĕgitim ve Araștırma Hastanesi/Istanbul Tıp Dergisi, Galenos Yayınevi tarafından basılmıștır.
Received/Geliș Tarihi: 19.08 .2019 Accepted/Kabul Tarihi: 19.11.2019 


\section{Introduction}

Treatment of progressive scoliosis of the immature spine presents several challenges. It has been shown that the rapid growth period of the thoracic spine is from birth to the age of 5 years, with a $50 \%$ increase in the spine length during this period (1). If left untreated during this period, progressive curves may result in significant thoracic deformity, resulting in life-threatening cardiopulmonary pathologies (2).

It is accepted in long-term studies that, fusion applied before five-years of age may have adverse effects on pulmonary function via disrupting the growth process of the thoracic cage, thus decreased thoracic spinal height is correlated with reduced forced vital capacity and is associated with low quality of life (3). Therefore, growth-friendly methods have gained popularity in most early-onset progressive scoliosis types, and in congenital deformities to control the progression of curves and to preserve natural growth (4-6). Various growing instruments have been developed which maintain spine alignment while allowing the spine and thoracic cage to grow. For this purpose, conventional and magnetically controlled growing rods and vertical expandable prosthetic titanium rib aim to delay definitive fusion surgery (7). In these methods, complications such as rod fracture, infection, crankshaft phenomenon, rigid and incompatible thoracic wall formation can be observed $(7,8)$. Therefore, non-invasive procedures like serial casting are accepted as an alternative treatment modality in early-onset scoliosis (2). In the literature, it has been shown that serial casting can be used to delay surgery by preventing risks and complications associated with recurrent surgical procedures in growth-friendly methods. Despite the current evidence confirming that the initiation of casting at an early age is an important factor in the success of the treatment, the effect of the curvature etiology on treatment outcomes is not clearly defined in the literature (2).

This study aimed to evaluate the efficacy of serial castings in young children with congenital scoliosis and to discuss whether serial casting can be used effectively to delay surgical procedures.

\section{Methods}

Ten patients with congenital scoliosis who underwent serial casting in a single center between 2016 and 2019 were included in the study. Patients under the age of 5 -years with a Cobb angle above 25 degrees with congenital scoliosis (falls into three categories; failure of formation, failure of segmentation and mixed), who had not undergone any surgical treatment, and who were followed for at least 12 months were included in the study. A minimum number of three casts were applied to all patients. Patients whose families refused casting treatment and who had a progression of the curvature more than 10 degrees in the course of casting were excluded from the study. Written consent was obtained from the parents of all patients.

Cast application was performed under general anesthesia on a modified Cotrel frame. Mehta modification of the Cotrel-Morel technique was used in cast application (9). The apex points of the kyphotic deformities were well padded to prevent skin lesions. The deformity is gently corrected by traction, derotation, and lateral pressure. The cast is molded over the rib hump to flatten it. An anterior window is made to relieve the chest and abdomen while preventing the lower ribs from rotating. No activity restriction was performed in patients. Casts were changed every 12 weeks. Radiographic evaluations were performed on posteroanterior and lateral orthoroentgenograms in the cast on the first day after the cast application and at the last follow-up visit.

The obtained data included age, Cobb angles of congenital coronal curves (angle formed by the intersection of two lines, one parallel to the endplate of the superior end vertebra and the other parallel to the endplate of the inferior end vertebra), sagittal deformity magnitude, coronal balance (measuring the distance between the central sacral vertical line and the plumb line), sagittal balance (measuring the distance between the posterosuperior aspect of the S1 vertebral body and the plumb line), thoracic height (The T1-T12 height was measured on full-length posteroanterior radiographs of the spine using the vertical distance from the middle of), number of cast applications, follow-up time and complications.

The study was approved by Metin Sabancı Baltalimanı Bone Diseases Training and Research Hospital Ethics Committee (decision no: 254 , date: 12.11.2018).

\section{Statistical Analysis}

SPSS 15.0 for Windows (IBM Corporation, Chicago, IL, USA) was used for statistical analyses. The descriptive statistic was expressed as numbers and percentages for categorical variables. The mean and the standard deviation were used as a numerical variable for normally distributed data. The mean of T1-S1 length, Cobb angle, Kyphosis angle, coronal and sagittal balance at the preoperative period, early postoperative period, and the late postoperative period were analyzed with Repeated measures ANOVA with a Greenhouse-Geisser correction. Post hoc tests using Bonferroni correction determined differences among preoperative, early postoperative, or late postoperative period. A $p$ value of $<0.05$ was considered to indicate significance. Inter-observer agreement was assessed using the " $\kappa$ " statistical test. A kappa value between 0.8 and 1 was considered a perfect agreement.

\section{Results}

A total of 10 patients ( 6 female, 4 male) with long congenital curves with mixed type formation or segmentation anomalies were included in the study. The mean number of cast applications was 4 for each patient (range: 3 to 6). The initial casting age was 3.2 (range: 2-4 years). The mean follow-up period was 15.1 months (range: 12-23 months). In two patients, the decision to perform a growing rod was made. In one of them, curve progression exceeded more than 10 degrees within the cast, and for the other, the parents of the patient refused further cast application.

The mean pre-casting Cobb angle was 61.9 \pm 13.7 degrees (range: 38 to 76 degrees), which was reduced to $43.4 \pm 12.8$ degrees (range: 24 to 58 degrees) after the initial casting, and it was $48.4 \pm 12.6$ degrees (range: 28-63 degrees) at the latest follow-up. When the pre-casting and after the initial casting values have been compared, we found that there was a statistically significant improvement $(p=0.001)$, but statistical significance was impaired when initial correction magnitude and last 
follow up values were compared $(p=0.275)$. The mean pre-casting T1T12 length was $223 \pm 27.3 \mathrm{~mm}$ (range: $176-271 \mathrm{~mm}$ ). After the initial cast application, T1-T12 length was 241.8 $\pm 27.5 \mathrm{~mm}$ (range: 189-285). At the last follow-up, the mean T1-T12 length was found to be $254 \pm 27.6$ $\mathrm{mm}$ (range: 198-290 mm). When the pre-casting, initial cast application, and last follow up values were compared, we found that statistically significant elongation was achieved $(p=0.001)$.

The mean pre-casting kyphosis angle was $28.8 \pm 8.2$ degrees (range: 20 45 degrees). It was reduced to $25.2 \pm 5.1$ degrees (range: 15-32 degrees) after the initial cast application and was measured as $26.7 \pm 6.2$ degrees (range: 17-38 degrees) at the last follow-up. We observed no significant change in the kyphosis angle $(p=0.242)$.

The mean pre-casting after initial casting and last follow-up lumbar lordosis angles were $37.1 \pm 11.4,34.3 \pm 12.2$, and $34.8 \pm 12.5$, respectively $(p=0.799)$. We did not observe a statistically significant improvement in coronal and sagittal balance values $(p=0.622$ and $p=0.066)$ (Table 1).

None of the patients had a neurological deficit or thoracic wall deformity. Two patients had mild skin irritation and improved with local wound care. In one patient, the cast treatment was temporarily terminated due to pneumonia and continued after the infection was resolved. The treatment of patients continues. Curvature was kept under control during one-year period, and no surgical treatment was required (Figure 1). Only in one patient, scoliosis progressed, and cast treatment was discontinued.

\section{Discussion}

Congenital spinal deformities have a broad spectrum ranging from mild asymptomatic curves to deformities that are concomitant with neurological and cardiopulmonary pathologies. The course of the deformity varies according to the localization and type of malformation and the age of the patient (10). Although the studies are limited, patients with congenital anomalies have been reported to have limited lung capacity, which can cause severe disability and even death if left untreated (5). Conservative treatment methods in congenital scoliosis are thought to be ineffective due to the rigid nature of the deformity but may have a corrective effect only on compensatory curves. Therefore, it has been reported that surgical treatment should be preferred if there is a high risk of progression in this patient group $(5,11)$. In selected patients with congenital scoliosis, convex hemiepiphysiodesis has been used as a growth-friendly surgical method for many years, but it has been shown that hemiepiphysiodesis may have unpredictable outcomes (12). However, hemiepiphysiodesis is still an invasive procedure regardless of technique and may not always result in the resolution of the deformity.

Table 1. General overview of the patient data

\begin{tabular}{|l|l|}
\hline & Preoperative \\
\hline T1-T12 length $(\mathrm{mm})$ & $223 \pm 27.3$ \\
\hline Cobb angle (degree) & $61.9 \pm 13.7$ \\
\hline T3-T12 kyphosis angle (degree) & $28.8 \pm 8.2$ \\
\hline L1-S1 lumbar lordosis (degree) & $37.1 \pm 11.4$ \\
\hline Coronal balance $(\mathrm{mm})$ & $17.5 \pm 17.11$ \\
\hline Sagittal balance $(\mathrm{mm})$ & $47.5 \pm 26.1$ \\
\hline
\end{tabular}

Various methods have been described for the cast application in scoliosis. The casting was first proposed 50 years ago by Cotrel and Morel for the treatment of scoliosis. Cotrel and Morel's EDF (elongation, derotation, flexion) correction technique is a frequently used conservative treatment modality (13). Cotrel and Morel stated that the technique is suitable not only to prevent progression but also to regress structural vertebral and thoracic deformities (13). One of the most commonly used methods is the Risser casting method applied from three points (14). This technique cannot adequately intervene in rotational abnormalities and can cause significant rib deformations and chest constriction, especially in younger children with the flexible bone (15). Due to the problems that emerged in growth-friendly surgical treatment modalities, serial casting treatment has gained popularity once more, and it has been shown that serial casting can provide successful results in idiopathic and non-idiopathic deformities $(2,16)$. Fletcher et al. (16) reported that spinal growth was sustained during the casting treatment in 12 idiopathic and 17 nonidiopathic scoliosis patients, and 39 months delay for the surgery had been achieved and $72.4 \%$ of the patients avoided growing rod surgery. In their series of 39 patients including 17 non-idiopathic scoliosis patients, Baulesh et al. (2) concluded that non-idiopathic deformities had less resolution of the deformity when compared to idiopathic deformities, on the other hand, the thoracic growth was sustained and the initial surgical procedure for the growing rod was delayed by an average of two years. In our study, the mean pre-casting T1-S1 length was $223 \pm 27.3$ $\mathrm{mm}$ (range: 176-271 mm). After initial casting, T1-S1 lengths were 241.8 $\pm 27.5 \mathrm{~mm}$ (range: 189-285). At the last follow-up, the mean T1-S1 length was measured to be $254 \pm 27.6 \mathrm{~mm}$ (range: $198-290 \mathrm{~mm}$ ). When we compared pre-casting, initial casting, and last follow-up values, we concluded that the growth was similar to other studies in the literature and was statistically significant $(p<0.05)$.

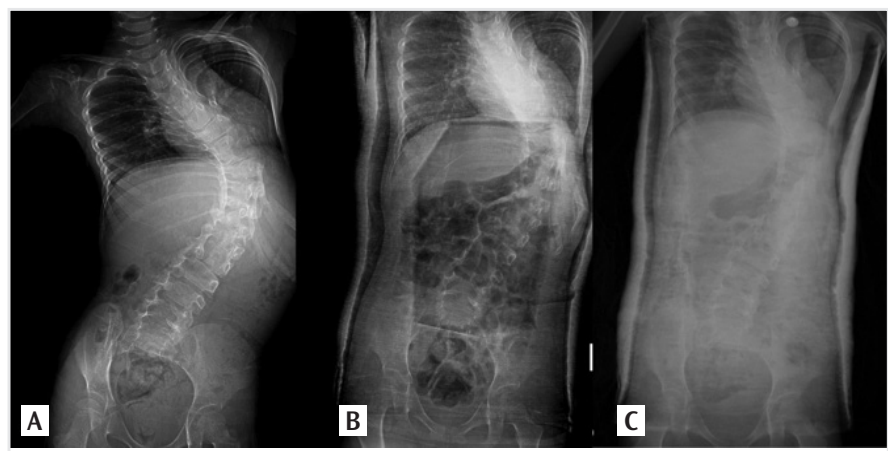

Figure 1. A) Twenty-eight month-old girl congenital scoliosis pre-casting posteroanterior radiography, B) after initial cast application, C) at five cast application

\begin{tabular}{|l|l|l|}
\hline Initial casting & Last follow up & $\mathbf{p}$ \\
\hline $241.8 \pm 27.5$ & $254 \pm 27.6$ & $<0.001$ \\
\hline $43.4 \pm 12.8$ & $48.4 \pm 12.6$ & $<0.001$ \\
\hline $25.2 \pm 5.1$ & $26.7 \pm 6.2$ & 0.242 \\
\hline $34.3 \pm 12.2$ & $34.8 \pm 12.5$ & 0.799 \\
\hline $15.9 \pm 7.6$ & $12.9 \pm 5.9$ & 0.622 \\
\hline $31.1 \pm 27.6$ & $35.1 \pm 23.3$ & 0.066 \\
\hline
\end{tabular}


In their study of 16 early-onset scoliosis (EOS) patients (8 idiopathic, 8 syndromic), Waldron et al. (17) stated that the Cobb angle decreased from 73 degrees to 45 degrees, and progression to surgery was observed in $31 \%$ of the patients and complications due to casting in $19 \%$. In their study, Demirkiran et al. (5) stated that the correction was obtained after the first cast application and was maintained during the treatment period, and the majority of the correction was provided during the first cast application, and the magnitude of the deformity correction was similar to the growing rod application. In our study, Cobb angle was 61.9 \pm 13.7 degrees (range: 38-76 degrees), which was corrected to $43.4 \pm 12.8$ degrees (range: $24-58$ degrees) after the initial casting, and it was $48.4 \pm 12.6$ degrees (range: $28-63$ degrees) at the latest followup. When we compared pre-casting and early post-casting values, we found that there was a statistically significant improvement $(p<0.05)$, but we found that statistical significance was impaired when we compared initial casting and last follow-up values $(p=0.275)$. Although the improvement achieved with the first casting was somewhat lost in the subsequent casts, the present correction could be preserved and saved us time for surgical treatment. In only one patient, due to the progression of the curvature, we switched to a growing rod, and we did not encounter any severe complications.

A potential disadvantage of the casting treatment is that it may have adverse effects on pulmonary function due to the advanced deformity of the rib cage, especially in patients with congenital scoliosis. Despite the deterioration of pulmonary parameters after the initial cast application, it was reported in the literature that it returned to the baseline values after the second cast application (18). In our study, we did not evaluate pulmonary functions before and after cast applications, but in our patient group, cast application was well tolerated in terms of pulmonary functions, and we did not encounter any problems. In one patient, the cast treatment was temporarily terminated due to pneumonia and continued after the infection had resolved. Two patients had mild skin irritation due to the insufficiency of skin and subcutaneous tissues. Between the cast changes, one week of rest and local care was given, and the skin irritation was resolved without any problems.

Although modern cast application requires general endotracheal anesthesia, it is far from surgical trauma, infection risk, and neurological complications that surgical treatment methods may cause. With cast treatment, the goal is to delay the surgery until sufficient vertebral growth has been achieved for satisfactory respiratory function (4). The purpose of treatment in EOS is to control the progression of deformity to delay or eliminate the need for spinal fusion without compromising normal spinal, thoracic, and pulmonary growth (6). Serial casting is an effective growth protection technique and is less invasive than the growth-friendly surgical techniques described. We estimate that most of the children in this study will be followed up with a growthpreserving surgical method following serial cast treatment. Regardless of the severity of the etiology of the deformity, we assume that serial cast treatment should be considered as an alternative method to delay growth-sparing surgery. The limitation of our study is the low number of patients and incomplete cast treatments.

\section{Conclusion}

We concluded that serial casting treatment is an effective alternative for delaying surgical interventions and avoiding surgical risks in congenital scoliosis patients.

Ethics Committee Approval: The study was approved by Metin Sabancı Baltalimanı Bone Diseases Training and Research Hospital Ethics Committee (decision no:254, date: 12.11.2018).

Informed Consent: Written consent was obtained from the parents of all patients.

Peer-review: Externally peer-reviewed.

Author Contributions: Surgical and Medical Practices - S.E., D.K., A.A.; Concept - D.K.; Data Collection and/or Processing - A.C..; Analysis and/or Interpretation - A.C..; Literature Search - S.E., E.A.Ü.; Writing Manuscript - S.E., E.A.Ü.

Conflict of Interest: No conflict of interest was declared by the authors.

Financial Disclosure: The authors declared that this study received no financial support.

\section{References}

1. Dimeglio A. Growth of the spine before age 5 years. J Pediatr Orthop Part B. 1992; 1: 102-7.

2. Baulesh DM, Huh J, Judkins T, Garg S, Miller NH, Erickson MA. The role of serial casting in early-onset scoliosis (EOS). J Pediatr Orthop 2012; 32: 658-63.

3. Karol LA. Early definitive spinal fusion in young children: what we have learned. Clin Orthop Relat Res 2011; 469: 1323-9.

4. Akbarnia BA, Campbell RM, Dimeglio A, Flynn JM, Redding GJ, Sponseller $\mathrm{PD}$, et al. Fusionless procedures for the management of early-onset spine deformities in 2011: what do we know? J Child Orthop 2011; 5: 159-72.

5. Demirkiran HG, Bekmez S, Celilov R, Ayvaz M, Dede O, Yazici M. Serial derotational casting in congenital scoliosis as a time-buying strategy. J Pediatr Orthop 2015; 35: 43-9.

6. Akbarnia BA, Cheung KM, Hilali N, Elsebaie H, Yazici M, Dannawi Z, et al. Next generation of growth-sparing techniques: Preliminary clinical results of a magnetically controlled growing rod (MCGR) in 14 Patients. Spine (Phila Pa 1976) 2013; 38: 665-70

7. Emans JB, Caubet JF, Ordonez CL, Lee EY, Ciarlo M. The treatment of spine and chest wall deformities with fused ribs by expansion thoracostomy and insertion of vertical expandable prosthetic titanium rib: Growth of thoracic spine and improvement of lung volumes. Spine (Phila Pa 1976) 2005; 30(17 Suppl): S58-68.

8. Akbarnia BA, Emans JB. Complications of growth-sparing surgery in early onset scoliosis. Spine (Phila Pa 1976) 2010; 35: 2193-204

9. Mehta MH. Growth as a corrective force in the early treatment of progressive infantile scoliosis. J Bone Joint Surg Br 2005; 87: 1237-47.

10. McMaster MJ, Ohtsuka K. The natural history of congenital scoliosis. A study of two hundred and fifty-one patients. J Bone Joint Surg Am 1982; 64: 1128-47.

11. Yazici M, Yilmaz G. The growing spine: Management of spinal disorders in young children. (Akbarnia BA, Yazici M, Thompson GH, eds.). Berlin, Heidelberg: Springer Berlin Heidelberg; 2011 
12. Uzumcugil A, Cil A, Yazici M, Acaroglu E, Alanay A, Aksoy C, et al. Convex growth arrest in the treatment of congenital spinal deformities, revisited. J Pediatr Orthop 2004; 24: 658-66.

13. Cotrel Y, Morel G. The elongation-derotation-flexion technic in the correction of scoliosis. Rev Chir Orthop Reparatrice Appar Mot 1964; 50: 59-75.

14. Risser JC. The application of body casts for the correction of scoliosis. Instr Course Lect 1955; 12: 255-9.

15. Sanders JO, D’Astous J, Fitzgerald M, Khoury JG, Kishan S, Sturm PF. Derotational casting for progressive infantile scoliosis. J Pediatr Orthop 2009; 29: 581-7.
16. Fletcher ND, McClung A, Rathjen KE, Denning JR, Browne R, Johnston CE. Serial casting as a delay tactic in the treatment of moderate-to-severe earlyonset scoliosis. J Pediatr Orthop 2012; 32: 664-71.

17. Waldron SR, Poe-Kochert C, Son-Hing JP, Thompson GH. Early onset scoliosis: The value of serial risser casts. J Pediatr Orthop 2013; 33: 775-80.

18. Cody Shafer MS, Robin Decoursey Jenson MAS, Stephen Dierdorf, Deann Martin, RNM, Shyam Kishan M. 6th International Congress on Early Onset Scoliosis and Growing Spine (ICEOS), November 15-16, 2012, Dublin, Ireland. J Child Orthop 2012; 6: 439-59. 